\title{
NEW KEYWORDS IN THE GEOSCIENCES - SOME CONCEPTUAL AND SCIENTIFIC ISSUES
}

\author{
Michael F. THOMAS
}

\begin{abstract}
New keywords in the geosciences such as geodiversity, geoconservation, geoheritage and geotourism are now in common use, with a rapid increase in the delineation of geosites and geomorphosites on the ground, usually with an intention to establish geoparks for promotion of geotourism and geoconservation. Geodiversity, as the abiotic equivalent of biodiversity, is argued by many to provide the foundation for delivery of ecosystem services. But others wish to define geosites separately for conservation of the geoheritage, while geodiversity defines geomorphosites as an input to geotourism. It is argued that geomorphosites are one category of geosite and commonly preserve essential features of the geoheritage, while understanding the dynamic status of component land facets and their connectivity are necessary to inform programmes for geoconservation.
\end{abstract}

Keywords: Geodiversity; geoconservation; geoheritage; geotourism; geosites.

\section{INTRODUCTION}

New keywords in the geosciences such as geodiversity, geoconservation, geoheritage and geotourism have developed a burgeoning new literature with its own journals and monographs. To match these topics and concerns a rapidly increasing number of geosites, geomorphosites (IAG) and geoparks are being proposed to define geographic areas of interest. With the recognition of Global Geoparks by UNESCO in 2015 this process will accelerate. In many countries these developments are expressions of cultural identity and concern for conservation of the geoheritage, and the development of geotourism is seen partly as a means to stimulate sustainable rural development. To secure public support for these initiatives the need for geoeducation is often stressed. The involvement of different scientific, and conservation organisations (IUGS, IAG, ProGeo, UNESCO) and national institutions (often geological surveys) has inevitably led to differences in aims, targets, scales of enquiry and terminology. Discussion of the dynamics of landscape and sensitivity of landscapes to land use pressures (including tourism), environmental perturbations, including climate change are often neglected in favour of description and the development of base surveys, when these interests should be seen as interdependent.
Although concerns for geoconservation predate the introduction of geodiversity as a specific field of enquiry, both have been described as 'emergent' concepts in the geosciences (HJORT et al. 2010, HENRIQUES et al. 2011), while the concept of geoheritage is often taken to hinge on the Digne declaration of 1991 concerning the 'rights of the memory of the earth', which has been adopted by many organisations, including USP and the IUGS, which has a Geoheritage Task Group (GTG). In Brazil, SIGEP (Comissão Brasileira de Sítios Geológicos e Paleobiológicos) in conjunction with CPRM (Serviço Geológico do Brasil) has developed a national inventory of geological and palaeontological sites of importance, and other countries are pursuing comparable programmes. In the UK, the Scottish Government launched a Geodiversity Charter in 2012, the work of the Scottish Geodiversity Forum, with support from the Scottish Government, Scottish Natural Heritage, the British Geological Survey and GeoConservationUK (BGS 2012). This followed a nationwide conference held in Edinburgh in 2009. These initiatives feed into a national policy on the environment and the development of Geotourism, which (per se) is neither science nor conservation but an aspect of general tourism. GATES (2006), offers a geologist's definition as 'tourism in geological landscapes', and distinguishes this from a wider geographic tourism. DOWLING \& 
NEWSOME (2006) also follow this distinction, while HOSE $(2008,2012)$ has named the ' 3 Gs' of geotourism as geohistory, geoconservation and geo-interpretation.

\section{GEODIVERSITY AND GEOSITES}

Although it is widely recognized that geodiversity as a topic has grown in part as a response to the well-established interest in biodiversity, it has secure roots in the histories of different branches of geoscience, and has been expressed in maps of geological and geomorphological provinces and landforms for more than a century. The former define tectonic, structural and age-related patterns of rocks, while the latter concern physiographic sub-divisions of the continents. Patterns of land were identified as land systems in the Australian CSIRO Land Resource Surveys from 1946 (CHRISTIAN \& STEWART 1953, 1968), and these also included land units and land facets in a hierarchy or scale and complexity. A review of this approach was published by TRICART \& KIEWEITDEJONGE in 1992. The concept of geodiversity (GRAY 2004, 2nd ed., 2013) also refers to definable attributes of variety expressed mainly in patterns of rocks, soils and landforms, and also including land cover, and most applications of geodiversity call for recognition of specific (mappable) units. The geotope (from the German geotop) (WIEDENBEIN 1994), for example, has been defined as the abiotic component of the ecotope, widely used in ecology and derived from the work of SØRENSEN (1936) and TANSLEY (1939). But this equivalence poses issues of scale: the ecotope is defined as the smallest mappable unit of land; home to a unique assemblage of organisms, and they should correspond with land facets as 'recurring landscape units of relatively uniform topography and soil' (BEIER \& BROST 2010, BROST \& BEIER 2012). The geotope on the other hand has been used to describe quite complex visual units on varied scales (FASSOULAS et al. 2012), and for different purposes: to define sites for geoconservation; to identify locations with geotourism potential, and as components of larger geoparks. The term is usually replaced by geosite, which has become paired with geomorphosite (REYNARD et al. 2016), but the scales of enquiry and descriptions of these units have also been highly variable. BORBA et al. (2016) have illustrated a field approach to geosite definition in the Serra do Segredo and Pedras das Guaritas
(Rio Grande do Sul), where they emphasize its 'relevance for structuring habitat, related with its functional or ecological support value'. Others have used modelling programmes utilising a wide range of geodata, from mineral grades to elevation points, to differentiate areal units in the earth sciences, and there are now many practitioners who would use geographic information systems (GIS) in preference other approaches to analysis and presentation (PIERIK et al. 2016). Interestingly, land facets have recently been advocated by BROST \& BEIER (2012) for mapping range and habitat conservation units in the face of climate change. Ecotopes (biotic), geotopes (abiotic), and land facets (holistic) should all be considered scaleequivalent mappable units, recognized in terms of uniformity. Based on current usage, geosites are components of the geodiversity of an area, but may be considered on different scales.

For plants and animals the water relations of ecotopes are essential properties (CRAWFORD 2008) and, beyond true deserts, also drive most geomorphological processes. Changing water relationships occur on every timescale, from storm events and seasonal changes, through periodicities of drought and flood, to long-term cyclical oscillations and trends of climate. In many locations inherent instability is expressed in terms of slope failures (landslides) and soil erosion by sheet flood and by gullying. Landscape sensitivity to change has been examined in many contexts and can be posited against the notion of resilience (THOMAS 2001). Indices of these properties are widely sought but often prove elusive in the real world. Ecologists also recognize that climatic factors can be dominant in influencing many plant distributions, which are also subject to global climate changes (CRAWFORD 2008).

Many authors have stressed that ecosystem function is dependent on specific geodiversity and geosystems, and that it is this combination of natural resources that delivers ecosystem services to local communities (GORDON et al. 2012, GORDON \& BARRON 2012, GRAY et al. 2013, HJORT et al. 2015). This interdisciplinary, community application of geodiversity studies is not always referenced in discussions centred on geoheritage and geotourism. A simplified representation of these relationships is offered in figure 1 .

\section{GEOSITES AND GEOHERITAGE}

Interest in geoheritage embodies the major concerns of the 'Rights of the Memory of the Earth' 
(Digne Convention 1991). The 4.5 bn 'memory' rests on the scientific value of key geosites, which record major stages of Earth history and shifting climates and, in a recent review, BRILHA (2016) (Figure 1) insists that geosites, representing the geoheritage must be considered separately from geodiversity sites, which relate more to geotourism. In practice most geodiversity sites will also be geomorphosites, and related to landscape character and evolution. But the separation of geosites from geomorphosites is difficult to justify, due to the essential connection between the exposure of rock formations and their settings in present-day landscapes. Furthermore, recent stages in Earth history are frequently preserved in the geomorphology, whether in terms of glacial history, fluvial development, the evolution of hillslopes or coastal morphology. The geoheritage preserved in the geomorphology is often from the Quaternary Era, but in many cratonic settings landscape features can be preserved or exhumed from remote geological eras (OLLIER 1991, OLLIER et al. 1988). These features are important components of both the geodiversity and the geoheritage of an area. BRUNO et al. (2014) have recently set out a set of principles for geosite classification, which gives priority to their paleogeographic significance: 'generally, they can be defined as geological heritage sites that represent paleoenvironments in general or highlight particular paleoenvironmental features, which are of special interest for science, education, or tourism/recreation.' The authors' list (BRUNO et al. 2014, Tables 1, 2) differs from that used by RUBAN (2010), but both seek to be inclusive and include geomorphology.

All branches of science converge on the view that our planet has increased in complexity (diversity) with time. Relicts of ancient rocks and landforms survive alongside ephemeral river bars that may be transformed by the next flood event or be abandoned and preserved with other legacies of past events and environments. Flights of river terraces, and successional moraines marking glacier retreat, along with deep karstification and chemical weathering are all examples of our geoheritage, many also contain fossil remains and artifacts marking the evolution of hominins and the development of cultures. There is no restriction of time period in the context of our geoheritage, which is continually evolving. It also exists at

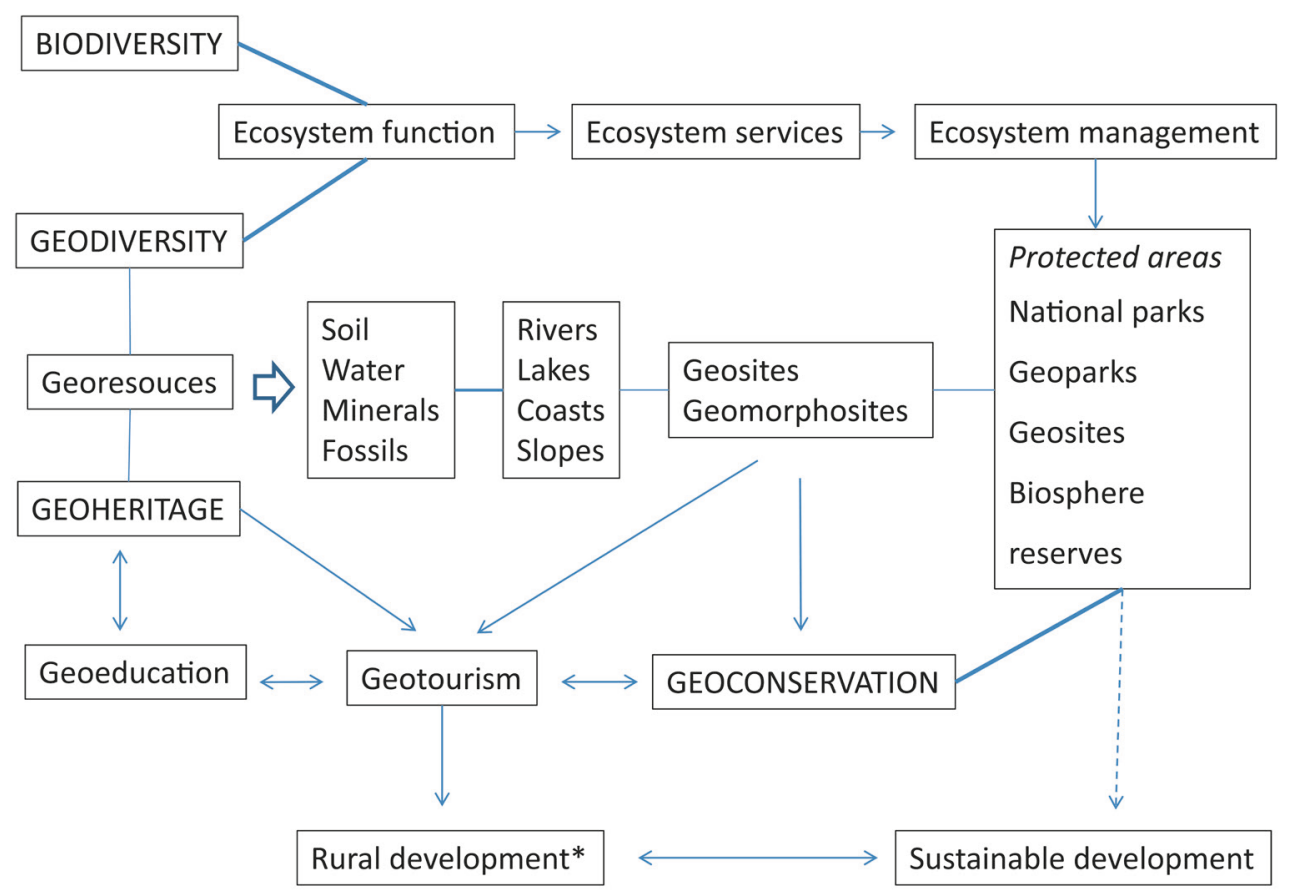

FIGURE 1 - Linkages between some 'new keywords' in common use *.

*Rural development and sustainable development are frequently linked to geotourism objectives and are primary objectives of ecosystem management. However, this opens another set of relationships which are not considered here. 
every spatial scale, from what can be seen under electron microscopy to our views of the planet from space. However, the patterns of forms and deposits that define geodiversity in a recognizable area are usually perceived at a landscape scale, although this in itself is highly variable. The mosaics (or tessera), which comprise these patterns are also palimpsests of forms and deposits of various ages, lithology and sensitivity to change (THOMAS 2001).

These patterns are all essential components of our geoheritage, even where a singular feature is the focus of interest. This is because of the connectivity that exists in most landscapes, between contiguous facets. The resilience or sensitivity to change of small land facets (ecotopes, geotopes) needs to be understood before geoconservation measures are taken to stabilise or conserve, geosites and geomorphosites. Moreover, change and remodelling of many geomorphosites are often reasons for their importance to geoscientists, engineers and even geotourists. Spectacular examples arise from volcanism, and ice-sheet margins, which fluctuate annually, and as a result of cyclical and secular changes of mass balance between snowfall and ablation. The link between Quaternary history, historic water fluctuation and connectivity is illustrated by the work of STEVAUX (1994), STEVAUX \& SANTOS (1998) and STEVAUX et al. (2013) on the Upper Paraná River and its wetlands. They conclude that, "connectivity can be better understood when applying a combination of mapping of geomorphologic units, vegetation units and hydrological information' (STEVAUX et al. 2013, p. 120).

\section{GEOCONSERVATION AND THE DYNAMIC NATURE OF GEOSITES}

These observations raise other conceptual issues, particularly for inventories and surveys of geosites. A recent review of these problems has been offered by REYNARD et al. (2016), while PELFINI \& BOLLATI (2014) cite a paper by BISCI \& DRAMIS (1991), which distinguishes active from inactive landforms, and applies their definition to the study of ongoing change in the landscape as a basis for geoconservation. Active landforms are defined as, 'those evolving under the action of the processes that generated them and are thus still evolving' (PELFINI \& BOLLATI 2014, after BISCI \& DRAMIS 1991). Those which are not active are regarded as passive, which leads to the concept of 'evolving passive geomorphosites' to describe active processes modifying passive forms (PELFINI \& BOLLATI 2014, p. 139). The most important question here is whether or not a particular landform or outcrop is undergoing active modification and change (or is susceptible to sudden failure). In many cases the most sensitive forms will be inherited forms and deposits, potentially unstable because of their survival in a changed process regime, as in paraglacial landscapes (BALLANTYNE 2002). Landforms that are a function of continuing processes may be changing rapidly (floodplains, cliff faces), but they are less likely to merit 'conservation' since their fluidity is inherent, and people will come to see the changes from season-to-season or year-toyear (calving glaciers and newly exposed slopes during rapid deglaciation). Many examples can be regarded as hazards, requiring mitigation and engineering intervention. Another aspect of landscape evolution is the long persistence and episodic re-adjustment affecting forms and deposits abandoned by their formative process systems, and most geomorphosites will possess complex combinations of recent and older features.

In the quest to determine the status of geomorphosites in terms of resilience or sensitivity to environmental change BERGER (1998) proposed the use of geoindicators. Two major contexts for such studies are landslides (CANUTI et al. 2004) and colluvium (EMADODIN et al. 2010). Both indicate periods or events leading to relatively rapid change to the land surface, and often also show evidence of repeated slope failure or sediment accumulation at the same sites. CANUTI et al. (2004, p. 908) observed that, "most of the current landslides in the Apennines are the reactivation of pre-existing ones, which have occurred in periods of climatic and geomorphological conditions different from those of the present.' Exceptions occur, particularly in crystalline rocks, where a weathered layer becomes stripped to reveal a resistant face of unaltered rock, which is then quite stable. Colluviation can be related to activity on hillslopes, but may also be induced by environmental and land-use changes in subdued terrain. Alternation of soil formation and phases of erosion $>$ deposition provide classic sections for dating of environmental change and land degradation, including archaeological investigation. All this implies that many landforms (or land facets) are neither relict nor continuously active. Extreme rainfall events often trigger slope instability, and may be clustered in time on annual, decadal, and on millennial scales due 
to climate change (THOMAS 2004, 2008). The resilience of undisturbed slopes can also be easily compromised by careless land use, which means that human activity in the landscape is integral to any geoconservation strategy.

The approach to these problem advocated by PELFINI \& BOLLATI (2014) would need some adjustment to give emphasis to these issues. Geosites may be active, inactive (metastable, dormant), or relict. Processes may be formational or transformational, in the sense that they may show continuity with the development of the existing relief form or may be actively transforming it towards a new equilibrium and morphology. There may also be connectivity between contiguous features, as when sedimentation takes place beyond a landslide toe, or swampy depressions develop beyond alluvial fans, while gullying will usually lead to sedimentation downstream in semi-arid environments. An approach to these issues is outlined in table 1. The dynamic status of any geosite will lie along a continuum from Active through Dormant to Relict. Each category will be subject to processes that either contribute to the formation of the feature or lead to its modification. Some processes are continuous but most are episodic, particularly those which are transformational. Connectivity will also often be highly variable over most time periods. On hillslopes at least, connectivity increases with rate and intensity of processes, and this is both a consequence and a cause of landscape instability and change.
It follows that geodiversity is an expression of the geoheritage and subject to change in dynamic Earth environments. Tectonic forces, periodicities and changes in climate and weather patterns, and human pressures, summarised as land use change, but including more direct impacts of tourism and site degradation from vandalism, challenge geoconservation. As shown in figure 2, perturbations due to geological and meteorological forces test any local geosystem resilience to change (sensitivity). As erosional thresholds are exceeded instability can lead to increased rates of change and to loss of geoheritage as well as to geohazards. Efforts in geoconservation will ideally re-establish stable conditions but seldom restore the original geoheritage, which has become modified, possibly with loss of value. Since change is inherent to all natural systems, understanding the nature and rates of environmental processes is vital to sustainable land management. Human impacts must also be measured across many time periods from the impacts of excavators and forest felling, mining and groundwater pumping, to millennia of occupation and agriculture (see THOMAS 2005, Table 1; RODRIGUES \& SILVA 2012).

\section{EVOLUTION OF GEOSITES - THE PALAEOCLIMATIC DIMENSION}

There is evidence in nearly all Earth environments of the imprints of past climates on the present landscape. Palaeo-lakes, -dunes, and -fans, tills and moraines, karstic features, river terraces and coastal barriers are but a few. It

TABLE 1 - Dynamic status and characteristics of geosites and geomorphosites.

\begin{tabular}{|c|c|c|c|c|}
\hline Dynamic State & $\begin{array}{l}\text { Process-form } \\
\text { relationship }\end{array}$ & Process activity/Rate & Connectivity & Resilience/Sensitivity \\
\hline Active - continuous & \multirow[b]{2}{*}{ Formational } & Continuous / Low - High & Low - High & \multirow{2}{*}{$\begin{array}{l}\text { Low - variable } \\
\text { (activity thresholds } \\
\text { frequently exceeded) }\end{array}$} \\
\hline Active - episodic & & $\begin{array}{c}\text { Episodic/ Intermittent } \\
\text { - High }\end{array}$ & High & \\
\hline \multirow{2}{*}{$\begin{array}{l}\text { Dormant } \\
\text { (inactive, } \\
\text { metastable) }\end{array}$} & $\begin{array}{c}\text { Transformational } \\
\text { (weathering/pedogenesis) }\end{array}$ & $\begin{array}{l}\text { Low / variable } \\
\text { (continuous) }\end{array}$ & \multirow{2}{*}{ Low } & \multirow{2}{*}{$\begin{array}{l}\text { Variable }- \text { high } \\
\text { (activity thresholds limit } \\
\text { activity to extreme events) }\end{array}$} \\
\hline & $\begin{array}{l}\text { Transformational } \\
\text { (erosion/deposition) }\end{array}$ & Episodic / High & & \\
\hline \multirow{2}{*}{$\begin{array}{c}\text { Relict } \\
\text { (inherited) }\end{array}$} & \multirow{2}{*}{$\begin{array}{c}\text { Transformational } \\
\text { (weathering/pedogenesis) }\end{array}$} & \multirow[t]{2}{*}{ Low (continuous) } & \multirow{2}{*}{$\begin{array}{c}\text { Low } \\
>>\text { Zero }\end{array}$} & $\begin{array}{c}\text { High } \\
\text { (Resistant to change, } \\
\text { activated by global changes) }\end{array}$ \\
\hline & & & & $\begin{array}{c}\text { Untested } \\
\text { (Remote from disturbance) }\end{array}$ \\
\hline
\end{tabular}




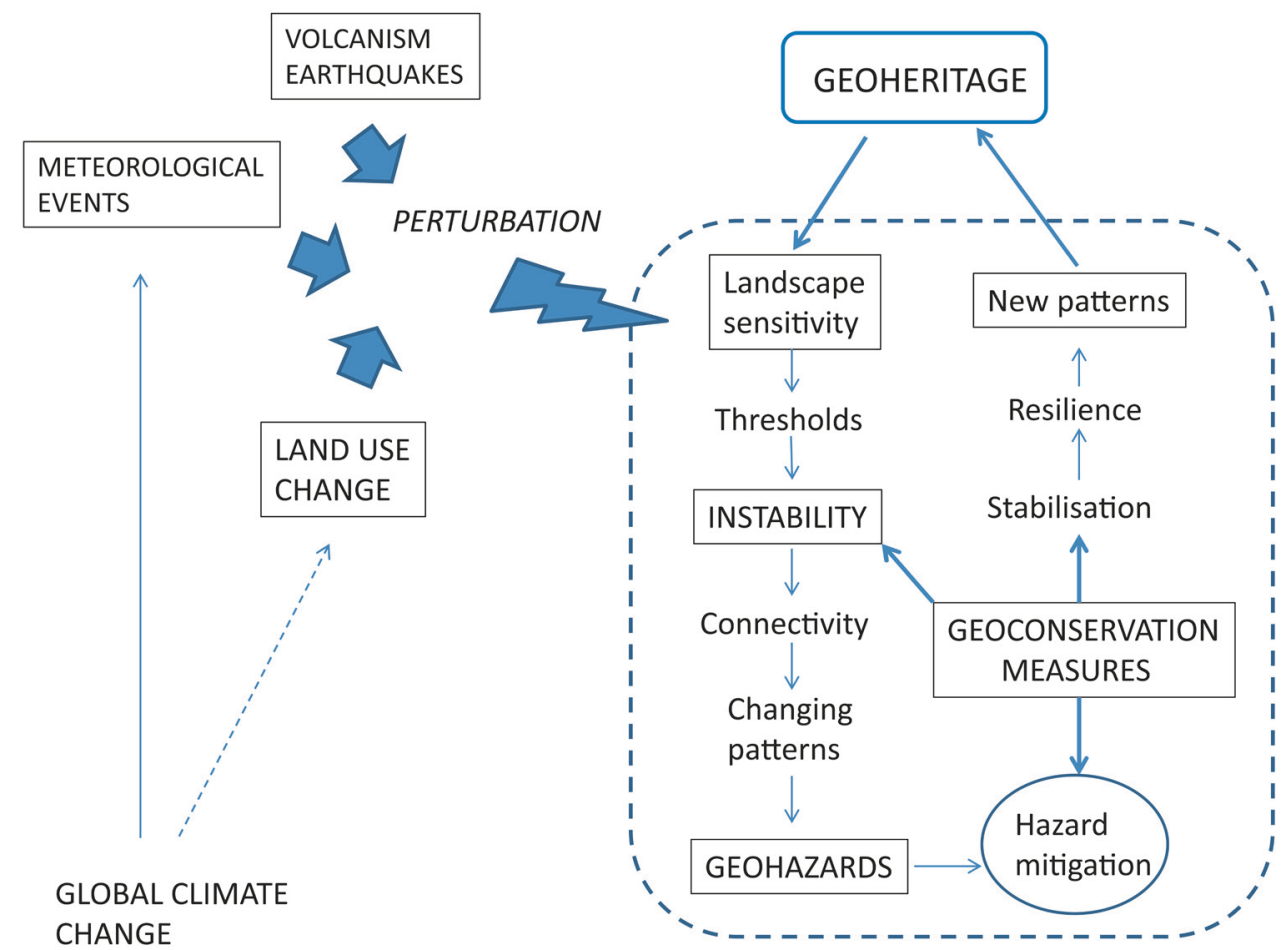

FIGURE 2 - Geodiversity, geoheritage and the forces for change. In this diagram external forces and internal land use change are identified as factors causing disturbance to geosystems and ecosystems.

follows that it is also important to understand the linkages between different parts of the landscape, where there is not always connectivity in terms of ongoing erosion and deposition. In the middle Rio Negro basin, for example, a range of forms and deposits can be seen (Figure 3) that tell a story of landscape evolution. These may not have direct implications for geoconservation, but they are relevant to geoeducation and geotourism and should inform ecosystem management. A full explanation requires contributions from petrology (properties of granite), geochemistry (products of weathering processes, dating), sedimentology (characteristics of fluvial and aeolian sediments), pedology (soil profile development) and geomorphology (landform origins and evolution).

With the passage of time most physical landscapes diversify as they change and evolve, and forms and deposits become superimposed on or partially replace more ancient features. This evolution clearly increases geodiversity at local and regional scales and inherited landforms and deposits often constitute the singular features, which have attraction for tourists and potential for geotourism. From the grandeur of tepuis, karstic caverns, great waterfalls and granite domes to vegetated palaeodunes, and islands in a river, all merit attention and, in most circumstances, geomorphologists can develop a conceptual model of the local landscape that can be communicated by various media.

Mass extinctions in geological history by definition reduced biodiversity and may have altered geodiversity. However, these episodes also emphasise the distinction between localised geological events and potentially global impacts on climate and biodiversity. The end Cretaceous or K-T event, associated with an asteroid impact in southern Mexico (Chicxulub crater, Yucatan) is such an example, and the great episodes of flood basalt extrusion such as the Paraná and the Etendeka Province linking Brazil with Namibia, or the so-called Deccan Traps of India (early and late Cretaceous) imposed a new geological uniformity over millions of $\mathrm{km}^{2}$ only to become disrupted by plate tectonic events of the Palaeogene. The Great Barrier Reef comprises a single major rock type extending over thousands of kilometres and, in its present form, is an expression of a singular event: rapid sea level rise between $14 \mathrm{ka}$ and $7 \mathrm{ka}$. But it 

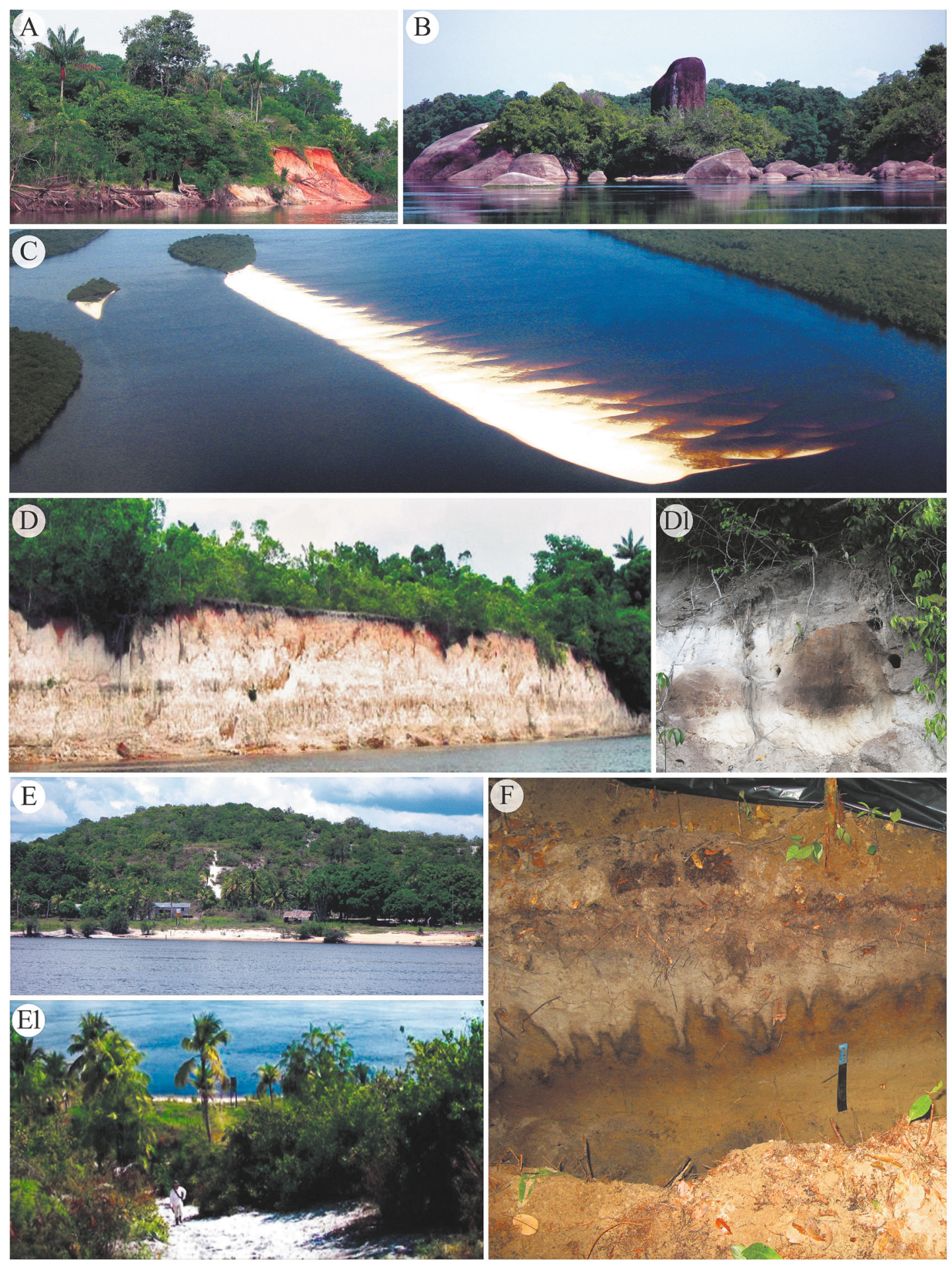

FIGURE 3 - Linkages between geomorphosites relevant to the Rio Negro, Amazonas. A) Crystalline granitoid rocks become weathered to varying depths; B) Fluvial erosion removes the weathered profile, liberating sand and clays into the river and exposing large boulders and rock surfaces; C) Sand becomes a major part of the bedload in the river forming river dunes and bars; D) Sand is also stored in older river terraces, where it becomes podzolised, D1; E) Aeolian palaeodunes, 30-40 m high have formed close to the channel during Late Quaternary dry climates (CARNEIRO FILHO et al. 2002); F) Within the forest, podzolisation appears to be overprinting latosols, possibly due to a shift to wetter climates during the Holocene (NASCIMENTO et al. 2004, 2008; FRITSCH et al. 2009, 2011). Photos by M.F.Thomas. 
also has an intricate sub-marine bio-geodiversity, where the biotic and abiotic realms combine to offer habitats supporting very high levels of marine biodiversity. The great Ergs of the northern Sahara or Namibia are similarly intricate in detail but show uniformity of substrate over large areas. These examples emphasise how important spatial scale, and global rarity, are when discussing geodiversity.

\section{GEODIVERSITY, GEOHERITAGE, AND GEOTOURISM}

The analysis and description of geodiversity for the identification of geoheritage sites or promotion of geotourism has become an important aspect of geodiversity studies and poses difficult questions. For example, does an area with a high index of geodiversity always win over another with lower scores, when it comes to georesources and geotourism? Extractive industry requires some continuity of ore deposits; large construction projects such as airports need (or must create) large uniform spaces for development. In contrast tourists will travel long distances to visit singular sites, often mountains such as Uluru (Ayer's Rock, Australia), the Sugarloaf Mountain (Rio de Janeiro), Table Mountain (Cape Town, RSA) and the iconic Monte Roraima and other Tepuis (Brazil, Guyana and Venezuela), or great waterfalls as at Iguaçu (Brazil, Argentina) and the Angel Falls (Venezuela).

With the rise of interest in and a desire to promote geotourism globally, new emphasis is also being given the creation of geoparks. UNESCO adopted Global Geoparks in 2015, and there are currently 120 Global Geoparks in 33 countries and the number is likely to increase rapidly. However at the time of writing there is just one UNESCO Global Geopark in Brazil (Global Geopark, Araripe) (MOCHIUTTI et al. 2012). On the other hand, according to BERNARD et al. (2014) Brazil has 220 million ha of protected land, the largest in the World, including 886 federal, 729 state, and 147 municipal CUs (unidades de conservação) that cover nearly 150 million ha. The CUs belong to different categories but are tasked mainly with conserving biodiversity and promoting sustainable development. MOREIRA \& MUGGLER (2014) have documented the rapid increase in interest and concern for the geoheritage in the last 20 years, calling for a change of strategy to emphasise the need for geoeducation and understanding of geodiversity. However, BERNARD et al. (2014) have also drawn attention to 93 events that have downgraded or downsized protected areas in the last 31 years, indicating that development pressures can override conservation goals.

There are also 68 national parks in Brazil, the oldest of which (Itatiaia) was created in 1937 and most are based on outstanding landscapes. But of the 20 UNESCO World Heritage Areas only 7 are inscribed on the basis of natural features. Responsibility for initiatives related to geoheritage rests with SIGEP (Comissão Brasileira de Sítios Geológicos e Paleobiológicos) within which the Geological Survey of Brazil (CPRM) has a key role in identifying and documenting geosites (167), and proposing future Geoparks, with 37 areas listed (SCHOBBENHAUS \& SILVA 2012, CPRM 2016), 17 of which have priority status (NASCIMENTO \& MANTESSO-NETO 2013). Many factors affect support for the creation of geoparks. ONARY-ALVES et al. (2015) and AVELAR et al. (2015) have both emphasised the need to raise local awareness, citing a proposal for 'Geopark Bodoquena Pantanal', in a remote rural area, and also 'Costões e Lagunas do Rio de Janeiro', which is peri-urban. MANSUR \& SILVA (2011) and AVELAR et al. (2015) both stress the importance of communication with society, citing the value of the 'Geological Paths Project' (Caminhos Geológicos) in the State of Rio de Janeiro. According to BACCI et al. (2009) and PIRANHA et al. (2011) the most important requirement is for improvements in earth science education. On the other hand in Campos Gerais do Paraná, GUIMARÃES et al. (2009) refer to the urgent need for geoconservation as a response to the exceptional values and threats to the regional geodiversity, including engineering works, collection of geological samples and inadequate land management, mainly linked to agriculture and forestry practices. The scale of some major features such as the Rio Negro-Solimões fluvial confluence (UNESCO, Central Amazon Conservation Complex), or the Pantanal wetlands creates many problems for geotourism, in terms of access and intervisibility. HOSE (2012), taking a global view, emphasizes that geohistory, geoconservation and geo-interpretation are all essential to geotourism.

\section{CONCLUDING COMMENTS}

Sections of the literature covering the "new keywords' discussed above appear to restrict geodiversity studies to rather few applications centred on geotourism and landscape conservation, while others argue for wider application to support 
the delivery of ecosystem services to society, and for conservation of the geoheritage. This paper argues for the latter and for greater emphasis on certain scientific aspects of these topics.

Neither geodiversity nor geoheritage denote unchanging properties of the geosphere. Magmatic and atmospheric processes ensure that the Earth's surface is continuously evolving towards an ever more complex state, as differential denudation of the continents leaves markers of the past history in the landscape, seen in rocks, sediments and landforms. These are all parts of the geoheritage, which includes not only the palaeontological evidence for evolution, but the archaeological evidence for cultural stages and land use. The evidence also contains the markers from past climates and extreme events in the Earth's history.

By describing and monitoring ongoing processes at key geomorphosites, the impacts of climate perturbation and change can be understood and mitigation policies developed. The adverse effects of land development can also be recorded and in many cases predicted. Only by including the dynamic aspects of geosites and geomorphosites in any appraisal for geotourism or other use can the geoheritage be guarded against attrition.

There are also deeper questions concerning geoeducation and communication with residents and visitors to tourist sites. Geoparks can be an important vehicle for developing new initiatives, but they are unlikely to reach a majority of destinations where tourists visit. For this reason the provision of descriptive materials for a much larger number of geosites in Brazil is a valuable initiative. The development of smartphone applications will become increasingly important, with examples now becoming available for many areas of China (ZHAO \& ZHAO 2011, LI et al. 2015), and the first iBook for Hong Kong already published for iPad (LI et al. 2015).

\section{ACKNOWLEDGEMENTS}

I should like to thank Dr Cristina Augustin of the Federal University of Minas Gerais (UFMG) for stimulating me to think about geodiversity in 2008, and for numerous field excursions; also Dr Nádia Regina do Nascimento for inviting me to join a field visit to the Rio Negro in 2009, and her colleagues, Guilherme Taitson Bueno, Rosely Pacheco Dias and Bruna Gomes Rossin for their company as we sailed up river for five days, and who were able to show me some of the key soil profiles examined in their research referenced here; also The Brazilian National Council for Scientific and Technological Development (CNPq) for financing my visits to Brazil.

\section{REFERENCES}

AVELAR, S.; MANSUR, K.L.; ANJOS, S.C.; VASCONCELOS, G.F. 2015. Community Perceptions for Geoconservation of a Coastal Area in Rio de Janeiro, Brazil. Geoheritage, 7: 275-283.

BACCI, C.D.; PIRANHA, J.M.; BOGGIANI, L.P.C.; TEIXEIRA, W. 2009. Geopark Strategy of Geoconservation and Educational Projects. Geologia USP, Publicação Especial, 5: 7-15.

BALLANTYNE, C.K. 2002. Paraglacial geomorphology. Quaternary Science Reviews, 21: 1935-2017.

BEIER, P.; BROST, B.M. 2010. Use of land facets to plan for climate change: conserving the arenas, not the actors. Conservation Biology, 24: 701-710.

BERGER, A.R. 1998. Environmental change, geoindicators, and the autonomy of nature. GSA Today, January 1998: 3-8.

BERNARD, E.; PENNA, L.; ARAÚJO, E. 2014. Downgrading, Downsizing, Degazettement, and Reclassification of Protected Areas in Brazil. Conservation Biology, 28: 939-950.

BISCI, C.; DRAMIS, F. 1991. Il concetto di attavita in geomorfologia. Geografia Fisicae e Dynamica Quaternaria, 14: 193-199.

BORBA, A.W.; SILVA, E.L.; SOUZA, L.P.M.; SOUZA, L.F.; MARQUES, R.V. 2016. Relação entre a geodiversidade intrínseca e a estruturação de habitat na escala do geossítio: exemplos na Serra do Segredo e nas Pedras das Guaritas (Caçapava do Sul, RS, Brasil). Pesquisas em Geociências, 43: 183-202.

BGS - BRITISH GEOLOGICAL SURVEY 2012. Scotland's Geodiversity Charter. Available at https://scottishgeodiversityforum.org/ charter/. Accessed on mar. 2016.

BRILHA, J. 2016. Inventory and quantitative assessment of geosites and geodiversity sites: a review. Geoheritage, 8: 119-134. 
BROST, B.M.; BEIER, P. 2012. Use of land facets to design linkages for climate change. Ecological Applications, 22: 87-103.

BRUNO, D.E.; CROWLEY, B.E.; GUTAK, J.M.; MORONI, A; NAZARENKO, O.V.; OHEIM, K.B.; RUBAN, D.A.; TIESS, G.; ZORINA, S.O. 2014. Paleogeography as geological heritage: Developing geosite classification. Earth-Science Reviews, 138: 300-312.

CANUTI, P.; CASAGLI, N.; ERMINI, L.; FANTI, R.; FARINA, P. 2004. Landslide activity as a geoindicator in Italy: significance and new perspectives from remote sensing. Environmental Geology, 45: 907-919.

CARNEIRO FILHO, A; SCHWARTZ, D.; TATUMI, S.H.; ROSIQUE, T. 2002. Amazonian Paleodunes Provide Evidence for Drier Climate Phases during the Late Pleistocene-Holocene. Quaternary Research, 58(2): 205-209.

CHRISTIAN C.S.; STEWART, G.A. 1953. Survey of the Catherine-Darwin Region, 1946. Land Research Series, CSIRO, Australia, 1.

CHRISTIAN, C.S.; STEWART, G.A. 1968. Methodology of integrated surveys. In: UNESCO, Aerial Surveys and Integrated Studies, UNESCO, Paris. Natural Resources Research, 6: 233-280.

CPRM - COMPANHIA DE PESQUISA DE RECURSOS MINERAIS. 2016. Geoparques. Available at http://www. cprm.gov.br/publique/Gestao-Territorial/ Geoparques-134. Accessed on 06 sept. 2016.

CRAWFORD, R.M.M. 2008. Plants at the Margin - Ecological Limits and Climate Change. CambridgeUniversityPress, Cambridge,478p.

DOWLING, R.; NEWSOME, D. (ed.). 2006. Geotourism. Elsevier, ButterworthHeineman, $260 \mathrm{p}$.

EMADODIN, I.; REISS, S.; BORK, H.I. 2010. Colluviation and soil formation as geoindicators to study long-term environmental changes. Environmental Earth Science, 62:1695-1706.

FASSOULAS, C.; MOURIKI, D.; DIMITRIOUNIKOLAKIS, P.; ILIOPOULOS, G. 2012.
Quantitative assessment of geotopes as an effective tool for geoheritage management. Geoheritage, 4: 177-193.

FRITSCH, E.; ALLARD, TH.; BENEDETTI, M. F.; BARDY, M.; NASCIMENTO, N.R.; LI, Y.; CALAS, G. 2009. Organic complexation and translocation of ferric iron in podzols of the Negro River watershed. Separation of secondary $\mathrm{Fe}$ species from $\mathrm{Al}$ species. Geochimica et Cosmochimica Acta, 73: 1813-1825.

FRITSCH, E.; BALAN, E.; NASCIMENTO, N.R.; ALLARD, T.; BARDY, M.; BUENO, G.; DERENNE, S.; MELFI, A.J.; CALAS, G. 2011. Deciphering the weathering processes using environmental mineralogy and geochemistry: Towards an integrated model of laterite and podzol genesis in the Upper Amazon Basin. Comptes Rendus Geoscience, 343(2-3): 188-198.

GATES,A.E. 2006. Geotourism: a perspective from the USA. In: R.K. Dowling \& D. Newsome (eds) Geotourism, Elsevier, p. 157-179.

GORDON, J.E.; BARRON, H.F. 2012. Valuing geodiversity and geoconservation: developing a more strategic ecosystem approach. Scottish Geographical Journal, 128: 278-297.

GORDON, J.E.; BARRON, H.F.; HANSOM, J.D.; THOMAS, M.F. 2012. Engaging with geodiversity - why it matters. Proceedings of the Geologists'Association, 122: 1-6.

GRAY, M. 2004. Geodiversity, valuing and conserving abiotic nature. John Wiley, Chichester, $2^{\text {nd }}$ edition, 2013, $434 \mathrm{p}$.

GRAY, M.; GORDON, J.E.; BROWN, E.J. 2013. Geodiversity and the ecosystem approach: the contribution of geoscience in delivering integrated environmental management. Proceedings of the Geologists' Association, 124: 659-673.

GUIMARÃES, G.B.; MELO, M.S.; MOCHIUTTI, N.F. 2009. The challenges of geoconservation in the Campos Gerais of Paraná (Desafios da Geoconservação nos Campos Gerais do Paraná). Geologia USP - Publicaçao Especial, 5: 47-61. 
HJORT, J.; GORDON, J.E.; GRAY, M.; HUNTER, M.J. 2015. Why geodiversity matters in valuing nature's stage. Conservation Biology, 29: 630-639.

HOSE, T.A. 2008. Towards a history of geotourism: definition, antecedents and the future. In: C.V. Burek \& C.D. Prosser (ed.) History of Geoconservation. Geological Society, London, Special Publication, 300: 37-60.

HOSE, T.A. 2012. 3 G's for geotourism. Geoheritage, 4: 7-24.

LI, Q.; TIAN, M.; LI, X.; SHI, Y.; ZHOU, X. 2015. Toward smartphone applications for geoparks information and interpretation systems in China. D Gruyter Open Geoscience, 1: 663677. Available at http://www.hkr2g.net/ ibook/ lso. Accessed on 3 feb. 2016.

MANSUR, K.L.; SILVA, A.S. 2011. Society's Response: Assessment of the Performance of the "Caminhos Geológicos" ("Geological Paths") Project, State of Rio de Janeiro, Brazil. Geoheritage, 3(1): 27-39.

MOCHIUTTI, N.F.; GUIMARAES, G.B.; MOREIRA, J.C.; LIMA, F.F.; DE FREITAS, F.I. 2012. The values of geodiversity: geosites of the Araripe Geopark, State of Ceará, Brazil (Os valores da geodiversidade: Geossítios do Geopark Araripe/CE). Anuário do Instituto de Geociências, 35: 173-189.

MOREIRA, J.C.; MUGGLER, C.C. 2014. Geodiversity and geoconservation in Brazil. Geophysical Research Abstracts,16: EGU 2014-13112.

NASCIMENTO, M.A.L.; MANTESSO-NETO, V.; 2013. Speleological heritage in Brazil's proposed geoparks, as presented in the book "Geoparques do Brasil: propostas". Tourism and Karst Areas, 6: 27-42.

NASCIMENTO, N.R.; BUENO, G.T.; FRITSCH, E.; HERBILLON, A.J.; ALLARD, TH.; MELFI, A.J.; ASTOLFO, R.; BOUCHER, H.; LI, Y. 2004. Podzolisation as a deferralitization process. A study of an Acrisol-Podzol sequence derived from Paleozoic sandstones in the northern upper Amazon Basin. European Journal of Soil Science, 55: 523-538.
NASCIMENTO, N.R.; FRITSCH, E.; BUENO, G.T.; BARDY, M.; GRIMALDI, C.; MELFI, A.J. 2008. Podzolization as a deferralitisation process: dynamics and chemistry of ground and surface waters in an Acrisol-Podzol sequence of the upper Amazon Basin. European Journal of Soil Science, 59: 911924.

OLLIER, C.D. 1991. Ancient Landforms. Belhaven Press, London, 233 p.

OLLIER, C.D.; GAUNT, G.F.M.; JURKOWSKI, I. 1988. The Kimberley Plateau, Western Australia a Precambrian erosion surface. Zeitschrift für Geomorphologie, N.F. 32: 239-246.

ONARY-ALVES S.Y.; BECKER-KERBER B.; VALENTIN P.R.; PACHECO M.L.A.F. 2015. O conceito de geoparque no Brasil: reflexões, perspectivas e propostas de divulgação. Terrae Didatica, 11: 94-107.

PELFINI, M.; BOLLATI, I. 2014. Landforms and geomorphosites ongoing changes: concepts and implications for geoheritage promotion. Quaestiones Geographicae, 33: 131-143.

PIERIK, H.J.; COHEN, K.M.; STOUTHAMER, E. 2016. A new GIS approach for reconstructing and mapping dynamic late Holocene coastal plain palaeogeography. Geomorphology, 270: 55-70.

PIRANHA, J.M.; DEL LAMA, E.A.; BACCI, D. 2011. Geoparks in Brazil - strategy of geoconservation and development. Geoheritage, 3: 289-298.

REYNARD, E.; PERRET, A.; BUSSARD, J.; GRANGIER L.; MARTIN, S. 2016. Integrated approach for the inventory and management of geomorphological heritage at the regional scale. Geoheritage, 8: 43-60.

RIBEIRO, L. C. B.; CARVALHO, I. DE S.; NETO F. M. 2014. Geopark Uberaba: relevance of the geological heritage. Geoheritage 7: 261273.

RODRIGUES, S.C.; SILVA, T.I. 2012. Dam construction and loss of geodiversity in the Araguari river basin, Brazil. Land Degradation \& Development, 23: 419-426. 
RUBAN, D.A. 2010. Quantification of geodiversity and its loss. Proceedings of the Geologists' Association, 121: 326-333.

SCHOBBENHAUS, C.; SILVA, C.R. 2012. Geoparques do Brasil: propostas. São Paulo: CPRM. Available at http://www.cprm.gov. br/publique/media/geoparquesdobrasil_ propostas. Accessed on 2 Sept. 2016.

SCOTTISH GEODIVERSITY FORUM. 2012. Scottish Geodiversity Charter. Avalilable at https://scottishgeodiversityforum.org/ charter/. Accessed on October, 2016.

SØRENSEN, T. 1936. Some ecosystematical characteristics determined by Raunkicer's circling method. Nordiska (19. skandinaviska) naturforskarmötet $i$ Helsingfors den 11-15 augusti 1936: 474-475.

STEVAUX, J.C. 1994. The Upper Paraná River (Brazil): geomorphology, sedimentology and palaeoclimatology. Quaternary International, 21: 143-156.

STEVAUX, J.C.; SANTOS, M.L. 1998. Palaeohydrological changes in the Upper Paraná River, Brazil, during the late Quaternary: a facies approach. In: G. Benito, V.R. Baker, K.J. Gregory (ed.), Palaeohydrology and Environmental Change. Wiley, Chichester, pp 273-285.

STEVAUX, J.C.; CORRADINI, F.A.; AQUINO, S. 2013. Connectivity processes and riparian vegetation of the upper Paraná River, Brazil. Journal of South American Earth Sciences, 46: 113-121.

TANSLEY, A.G. 1939. The British Isles and Their Vegetation. Vol. 1 of 2. Cambridge, United Kingdom. 494 p.

THOMAS M.F. 2001. Landscape sensitivity in time and space - an introduction. Catena, 42 : 83-98.
THOMAS, M.F. 2004. Landscape sensitivity to rapid environmental change - a Quaternary perspective with examples from tropical areas. Catena, 55: 107-124.

THOMAS M.F. 2005. Landscape sensitivity and timescales of landscape change. In: J.A. WIENS \& M.R. MOSS (ed.) Issues and Perspectives in Landscape Ecology. Cambridge University Press, Cambridge, p. 131-151.

THOMAS, M.F. 2008. Understanding the impacts of late Quaternary climate change in tropical and sub-tropical regions. Geomorphology, 101: $146-158$

THOMAS, M.F.2011. Sources of geomorphological diversity in the tropics. Revista Brasileira de Geomorfologia, 12: 47-60.

THOMAS, M.F. 2012a. Geodiversity and landscape sensitivity: A geomorphological perspective. Scottish Geographical Journal, 128(3-4): 1-16.

THOMAS, M.F. 2012b. A geomorphological approach to geodiversity - its applications to geoconservation and geotourism. Quaestiones Geographicae, 31: 81-89.

TRICART, J.; KIEWEITDEJONGE, C. 1992. Ecogeography and Rural Management. Longman, Harlow, $267 \mathrm{p}$.

WIEDENBEIN, F.W. 1994. Origin and use of the term 'geotope' in German-speaking countries. In: D. O'halloran, C. Green, M. Harley, \& J. Knill (ed.) Geological and Landscape Conservation. London, Geological Society, p. 117-120.

ZHAO Y.; ZHAO J. 2011. The development and key technology of the electronic guide system based on GIS and mobile phone. Digital Technology and Application 2011: 51-52.

Author's address:

Michael F. Thomas - Department of Biological \& Environmental Sciences, School of Natural Sciences, University of Stirling, Fk9 4la, Stirling, Scotland.E-mail: m.f.thomas@stir.ac.uk

Manuscript submitted in 13 September 2016 as an Invited Paper, accepted in 25 October 2016. 